\title{
Feed intake and performance of growing lambs raised on concentrate-based diets under cafeteria feeding systems
}

\author{
A. B. Rodríguez ${ }^{\dagger}$, R. Bodas, B. Fernández, 0. López-Campos, A. R. Mantecón and F. J. Giráldez \\ Estación Agrícola Experimental (CSIC), Finca Marzanas, Grulleros, 24346 León (Spain)
}

(Received 31 March 2006; Accepted 6 November 2006)

\begin{abstract}
Two trials were undertaken to study the effects of cafeteria feeding systems on the feed intake, animal performance and carcass characteristics of growing lambs. Trial 1 was designed to compare conventional and cafeteria feeding systems in terms of the growth of individually reared lambs. For this assay, 26 weaned Merino lambs (15.5 $\pm 0.20 \mathrm{~kg}$ live weight) were assigned to three dietary treatment groups: (1) a control group fed barley straw and commercial concentrate under a conventional feeding system, (2) group W100S, fed soya-bean meal, whole barley grain and a mineral-vitamin supplement under a cafeteria feeding system, and (3) group W100S-T, fed as in the W100S treatment but allowing the lambs an initial training period so they could learn to identify a number of feeds. The feeding system had no significant effect $(\mathrm{P}>0.05)$ on either average daily live-weight gain, carcass weight, or carcass conformation. The food conversion ratio was lower $(\mathrm{P}<0.05)$ for the cafeteria-reared animals ( $2.9 \pm 0.16$ v. $2.5 \pm 0.08 \mathrm{~g}$ dry-matter intake per $g$ average daily gain) than those of the control group. This might be related to the higher crude protein intake seen in the cafeteria groups (150 \pm 5.6 v. $208 \pm 12.5 \mathrm{~g}$ per animal per day; $\mathrm{P}<0.001)$.

In trial 2, cafeteria and conventional feeding system were compared in terms of the growth of feedlot lambs. Two hundred weaned Merino lambs $(13.1 \pm 0.10 \mathrm{~kg})$ were divided into two experimental groups: (1) a control group, offered commercial concentrate and barley straw, and (2) a cafeteria group fed the same diet as W100ST in trial 1. The average daily gain (282 \pm 5.8 and $309 \pm 6.5 ; \mathrm{P}<0.01)$ was greater in the cafeteria than in the control group. Whereas neither carcass conformation nor fatness were affected by the feeding system, the dressing percentage was slightly higher $(\mathrm{P}>0.001)$ in the conventional than in the cafeteria system lambs.

The use of cafeteria systems for fattening lambs can improve the feed conversion efficiency and body growth rate over those achieved with conventional feeding systems, although the crude protein intake in these systems seems to be in excess of requirements.
\end{abstract}

Keywords: barley, carcass composition, food preferences, lambs, training of animals

\section{Introduction}

In Mediterranean countries, lambs are traditionally slaughtered for consumption at a low body weight $(25$ to $30 \mathrm{~kg})$ (Sañudo et al., 1996; Russo et al., 2003). The production of fattening lambs commonly occurs on big farms where animals are usually fed cereal straw and concentrate ad libitum. When such feeding systems are employed, straw intake is very low, usually less than $15 \%$ of the diet (Manso et al., 1998; Landa et al., 2001).

Even though straw makes up a low proportion of the diet, its use has an important impact on the economy of farms since large facilities are required for its storage. Moreover, this feed is usually manually distributed, which

\footnotetext{
${ }^{\dagger}$ E-mail: rganabel@hotmail.com
}

has a negative effect on labour costs. Removing cereal straw from the diet would therefore offer a way of reducing both labour and storage costs. Several studies have shown that straw could be completely removed from the diet of fattening lambs with no negative impact on animal performance if whole cereal is provided (Tait and Bryant, 1973; Landa et al., 2001; Cañeque et al., 2003).

When concentrate is not pelleted or ground, animals can select among the different ingredients; the composition of the concentrate can therefore change over the day. The efficient selection of the different ingredients would probably not be a problem with individually penned animals, as has been shown in most experimental trials. However, in feedlot systems, the opportunities for dietary selection would not be the same for all animals and this could affect animal performance and carcass quality. An alternative 
would be to use a cafeteria system, in which the composition of the offered foods would not change over time. Recently, Sahin et al. (2003) reported that Awassi lambs raised under a cafeteria feeding system successfully selected the diet to match their nutritional requirements and showed a performance similar to lambs raised under a conventional feeding system. Similar results have been reported by Görgülü et al. (1996) and Kyriazakis and Oldham (1993).

The literature on diet selection in growing lambs mainly refers to animals older than 3 months; studies performed with lambs during the period immediately after weaning are scarce. In addition, although a training period was allowed in some of these studies, it would be better to avoid this under commercial conditions. The aim of the present work was to compare food intake and animal performance during the period immediately after weaning in lambs reared under conventional and cafeteria feeding systems, with and without a training period.

\section{Material and methods}

\section{Animals and diets}

This study involved two trials. Trial 1 involved 26 male Merino lambs weaned at approximately 6 to 7 weeks of age. Creep feeding was made available from 3 weeks of age. Prior to weaning, the animals were dewormed by dosing with Ivomec (Merial Labs, Spain), and vaccinated against enterotoxaemia (Miloxan, Merial Labs, Spain). At weaning, the animals were weighed and housed individually in similar $1.5 \times 1.5 \mathrm{~m}$ pens in a naturally ventilated animal house. They were then assigned to one of three feeding systems groups until they reached a target slaughter weight of $25 \mathrm{~kg}$ : (1) a control group (no. $=10$ ) offered barley straw and a commercial pelleted concentrate ad libitum in different troughs. The concentrate consisting of (per $\mathrm{kg}$ dry matter) $460 \mathrm{~g}$ barley, $210 \mathrm{~g}$ soya-bean meal (SBM), $120 \mathrm{~g}$ maize, $100 \mathrm{~g}$ oat, $50 \mathrm{~g}$ bran, $14 \mathrm{~g}$ molasses, $16 \mathrm{~g}$ bypass fat and $30 \mathrm{~g}$ mineral-vitamin mix; (2) group W100S (no. = 8), fed whole barley grain (WBG), SBM and a mineral-vitamin mix (ad libitum in three separate troughs) and (3) W100S-T (no. = 8), fed the same as the W100S group with the animals allowed an initial training period of 4 days. The mean live weight (LW) of animals in each group was similar $(15.5 \pm 0.20 \mathrm{~kg})$. The position of the troughs for each feed was randomly assigned across pens; this order remained unchanged during the trial. During the training period, half of the lambs had access to WBG for 2 days and to SBM for the following 2 days. The remaining animals were fed the same feeds but in the opposite order. After training, the W100S-T lambs had free access to the different feeds.

Trial 2 was designed to evaluate the efficacy of the cafeteria system under commercial conditions. In this experiment, 200 weaned Merino lambs, half males (mean LW $13.1 \pm 0.10 \mathrm{~kg}$ ) and half females (mean LW
$13.0 \pm 0.09 \mathrm{~kg}$ ), were distributed into two groups $(50: 50$ male-female). The control group was fed commercial concentrate and barley straw ad libitum. The cafeteria group was given ad libitum and separately WBG, SBM and vitamin-mineral supplement. Each group was housed in an $8 \times 10 \mathrm{~m}$ floor pen containing two metal troughs for offering the different feeds. In the cafeteria pen, another smaller feeder was included for providing the vitamin-mineral supplement. Table 1 shows the chemical composition of the experimental feeds used in both trials.

\section{Experimental procedure}

Trial 1 was performed between March and April under natural daylight and temperature conditions at the research farm of the Experimental Agriculture Station (EAE; belonging to the Spanish Council for Scientific Research (CSIC)) in León, Spain. Animal handling followed the recommendations of the European Commission (2003).

The experimental feeds were offered unmixed once a day. The quantities of the different feeds offered and refused were weighed daily and samples were collected for analyses. The amount of feed offered was adjusted every day on the basis of the previous day's intake; with refusals of 15 to $20 \%$ of the maximum previous intake allowed (all animals complied). LW was recorded three times per week before morning feeding. Lambs were slaughtered individually when each lamb reached an LW of $25 \mathrm{~kg}$. Slaughter was carried out by anaesthetisation with sodium pentobarbitone and desanguination via the jugular vein. They were then skinned and eviscerated. The body of each lamb was dissected into carcass and noncarcass and the weights of the different components recorded. The carcass was chilled at $4^{\circ} \mathrm{C}$ for $24 \mathrm{~h}$ and then weighed again (cold carcass weight: CCW). The dressing percentage was calculated as the CCW expressed as a proportion of the slaughter weight. Carcasses were scored visually for conformation ( $1=$ poor, $5=$ excellent $)$ (Colomer-Rocher et al., 1988) and for external fatness ( 1 = limited, $4=$ important) according to European Commission (1994). The carcass compact index was calculated

Table 1 Chemical composition ( $\mathrm{g} / \mathrm{kg} \mathrm{DM}$ ) of the experimental feeds used in trials 1 and $2^{+}$

\begin{tabular}{lrlll}
\hline \hline & CP & NDF & Ash & EE \\
\hline Trial 1 & & & & \\
$\quad$ Concentrate & 175 & 159 & 84 & 45 \\
$\quad$ Barley straw & 35 & 813 & 47 & 12 \\
$\quad$ Whole barley & 124 & 213 & 26 & 25 \\
$\quad$ Soya-bean meal & 470 & 118 & 81 & 11 \\
Trial 2 & & & & \\
Concentrate & 167 & 174 & 70 & 31 \\
Barley straw & 21 & 797 & 60 & 12 \\
$\quad$ Whole barley & 114 & 188 & 23 & 26 \\
$\quad$ Soya-bean meal & 468 & 135 & 71 & 11 \\
\hline \hline
\end{tabular}

${ }^{\dagger} \mathrm{CP}$ : crude protein; NDF: neutral detergent fibre; EE: ether extract. 
by dividing the CCW by the carcass external length, and the buttock/pelvic limb ratio by dividing the buttock width by the pelvic limb length (Colomer-Rocher et al., 1988).

Trial 2, which lasted 52 days, was conducted on a commercial farm. Animals were assigned to two floor pens in a semi-open and naturally ventilated animal house. Except for the straw, all feeds were provided using an automatic distribution system. In the Control group, the straw was distributed daily by the farm workers. Refused feed was removed and weighed weekly. Samples of the offered and refused feeds were taken every week and analysed for their dry matter content. The mean daily feed intake for the whole fattening period was calculated by dividing the total feed intake by the product of the number of lambs and the number of days of the trial. During the trial, all lambs were individually weighed once a week according to the procedure of the farm. On day 38, all animals showing a LW of $>25 \mathrm{~kg}$ were transferred to a commercial abattoir and slaughtered. The remaining animals were slaughtered at the end of the experimental period (day 52). CCW was recorded $24 \mathrm{~h}$ after slaughter. Carcass conformation, compactness and fatness were determined as described in trial 1.

\section{Analytical procedures}

The procedures outlined by the Association of Official Analytical Chemists (2003) were used to determine the dry matter (DM, method ID 934.01), ash (method ID 942.05), Kjeldahl N (CP, method ID 984.13) and crude fat content (method ID 960.39) of the offered feeds. Neutral-detergent fibre (NDF) was determined by the procedure of Van Soest et al. (1991), using sodium sulphite in the neutral-detergent solution. Alpha-amylase was only included in the NDF assay for WBG and SBM.
Calculations and statistical analysis

Diet selection patterns were traced by plotting the cumulative difference between the intakes of WBG and SBM $(C D=$ WBG-SBM $)$ against the cumulative feed intake $(\mathrm{CFI}=\mathrm{WBG}+\mathrm{SBM})$, as described by Kyriazakis et al. (1990). The crude preference values were calculated dividing the consumption of SBM by the total feed consumption (WBG + SBM) as described Robertson et al. (2006). Daily weight gain was estimated as the regression coefficient of the LBW against time (using the REG procedure; Statistical Analysis Systems Institute (SAS), 1999). Data were analysed by one-way ANOVA to determine the effects of the feeding systems, recognising that, in trial 2 feeding system was confounded totally with pen. In trial 1, orthogonal contrasts were used to test the differences between the control and cafeteria feeding (control v. W100S + W100ST) groups, or between the two cafeteria groups (W100S v. W100S-T). All analyses were performed using the GLM procedure SAS (1999).

\section{Results}

In trial 1, two lambs in the W100S-T group had to be removed due to leg lesions; their data were excluded from analysis. Intake of organic matter tended $(P<0.083)$ to be greater in the control group than in the cafeteria groups (Table 2). No significant $(P>0.05)$ differences were seen among dietary treatments in daily LW gain. Nevertheless, the feed/LW gain ratio was significantly influenced $(P<0.05)$ by the feeding system, with the lowest values corresponding to the W100S and W100S-T groups. Control lambs utilised $\mathrm{CP}$ more efficiently than those in the cafeteria groups $(P<0.01$, Table 2$)$.

As expected, the concentrate formed the major component of the control group diet, straw intake making up $<10 \%$. The lambs that underwent a training period

Table 2 Feed intake, average daily weight gain (ADG) and feed to gain ratio (FCR) of lambs individually reared (trial 1) on conventional (control group) or cafeteria (W100S and W100S-T groups) feeding systems

\begin{tabular}{|c|c|c|c|c|c|c|}
\hline & \multirow[b]{2}{*}{ Control $(n=10)$} & \multicolumn{2}{|c|}{ Cafeteria systems } & \multirow[b]{2}{*}{ Residual s.d. } & \multicolumn{2}{|c|}{ Significance $^{\dagger}$} \\
\hline & & W100S $(n=8)$ & W100S-T $(n=6)$ & & P1 & $\mathrm{P} 2$ \\
\hline Dry-matter intake (DMI, g/day) & 889 & 835 & 795 & 101.1 & & \\
\hline Organic-matter intake (g/day) & 817 & 773 & 722 & 95.8 & $\mathrm{t}$ & \\
\hline Concentrate intake (g/day) & 850 & - & - & - & - & - \\
\hline Barley straw (g/day) & 39.1 & - & - & - & - & - \\
\hline Whole barley grain intake (g/day) & - & 535 & 353 & 94.4 & - & * \\
\hline Soya-bean meal intake (g/day) & - & 271 & 408 & 95.3 & - & $\neq$ \\
\hline Mineral-vitamin mix intake (g/day) & - & 29.0 & 35.1 & 7.4 & - & \\
\hline \multicolumn{7}{|l|}{ Food conversion ratio } \\
\hline g DMI per g ADG & 2.91 & 2.58 & 2.40 & 0.463 & * & \\
\hline g CP per g ADG & 0.49 & 0.60 & 0.71 & 0.108 & ** & $\neq$ \\
\hline Average daily gain (ADG, g/day) & 312 & 324 & 334 & 50.0 & & \\
\hline Days on trial & 31.5 & 31.3 & 34.6 & 7.57 & & \\
\hline
\end{tabular}

${ }^{\dagger} \mathrm{P} 1=$ probability for control $v$. cafeteria contrast; $\mathrm{P} 2=$ probability for W100S $v$. W100S-T contrast.

${ }^{\ddagger}$ Approaching significance $(P<0.10)$. 
consumed a greater proportion of SBM and lower of WBG than $\mathrm{W} 100 \mathrm{~S}$ lambs. The mean percentage intake values for WBG, SBM and mineral-vitamin mix for the entire experimental period were, respectively, 63.1 (s.e. 3.96), 32.9 (s.e. 4.09) and 4.0 (s.e. 0.44) for the W100S group, and 42.7 (s.e. 2.27), 51.0 (s.e. 2.28) and 6.3 (s.e. 1.01) for the W100S-T group. The crude preference values for SBM in W100S and W100S-T treatments were 0.34 (s.e. 0.043) and 0.55 (s.e. 0.025 ) respectively.

Figures 1 and 2 show there was a strong individual variation in the diet selection pattern. In the W100S group, most of the lambs consumed more WBG than SBM from the beginning to the end of the experimental period, although the percentage of WBG varied between 47 and $77 \%$. In the W100S-T group, most of lambs showed a preference for the SBM, but its percentage contribution to the selected diet also varied over a wide range (41 to $60 \%$ ).

In trial 1, differences in the dressing percentage between the control and cafeteria group showed a trend towards significance $(P=0.09)$, Control animal tended to have higher dressing percentage than cafeteria animals (Table 3). No significant differences or trends $(P>0.10)$ were observed between feeding systems in terms of carcass conformation, compactness or fatness.

The feeding system did not affect $(P>0.05)$ the blood or white and red offal weights (see Table 3). Nevertheless, the weights of the digestive fat deposits were greater and the wool weight lower (both $P<0.05$ ) in the control group than in the cafeteria system animals.

In Trial 2, the mean values for total DM intake for the control and cafeteria animals were 898 and $830 \mathrm{~g}$ DM per animal per day, respectively. Figure 3 shows the trend in the diet selection pattern of the cafeteria group. The figure shows the animals to have a slight preference for SBM. The proportions of the different feed ingredients in the diet consumed by the cafeteria lambs were: $46 \%$ WBG, $51 \%$ SBM, and 3\% mineral-vitamin mix. The average LW gain was $9 \%$ greater $(P<0.001)$ for the lambs in the cafeteriafed pen than the lambs in the control pen.
Carcass conformation, compactness and fatness were not significantly affected by the feeding system $(P<0.05$, Table 4).

\section{Discussion}

It has been suggested that, given the choice, animals try to minimise excess nutrient intake in order to maximise feed efficiency (Arsenos and Kyriazakis, 1999; Ferguson et al., 1999). Therefore, according to theoretical nutritional requirements, it would be expected that lambs in the cafeteria feeding system would consume higher proportions of WBG than protein supplement since $20 \%$ SBM would provide enough protein to meet their requirements. Nevertheless, the pattern of diet selection of the cafeteria feeding lambs did not support this hypothesis. In fact, although the W100S lambs showed a moderate preference for WBG, the consumption of SBM was greater than expected. Consequently, in the present study, the protein supply in the cafeteria feeding systems was theoretically in excess of the animals' tissue requirements (Agricultural and Food Research Council, 1995) and the efficiency of utilisation of $\mathrm{CP}$, in terms of LW gain, was worse in these groups than in the control group.

The training period did not reduce the trend for high protein intake by lambs reared under the cafeteria feeding systems. On the contrary, the animals of this group consumed a greater amount of SBM and therefore protein supply was also higher. Obviously, it is possible that the training period was insufficiently long to teach the animals the different post-ingestion effects of the different foods. However, Keskin et al. (2004), who used a training period longer than that of the present study, also observed that lambs reared in a cafeteria feeding system consumed more protein than those fed the same ingredients in a mixed feed. Similar results were reported by Fedele et al. (2002) in goats. Moreover, Tolkamp and Kyriazakis (1997) reported that, in dairy cows, a training period did not result in a more consistent diet choice after the adaptation period.

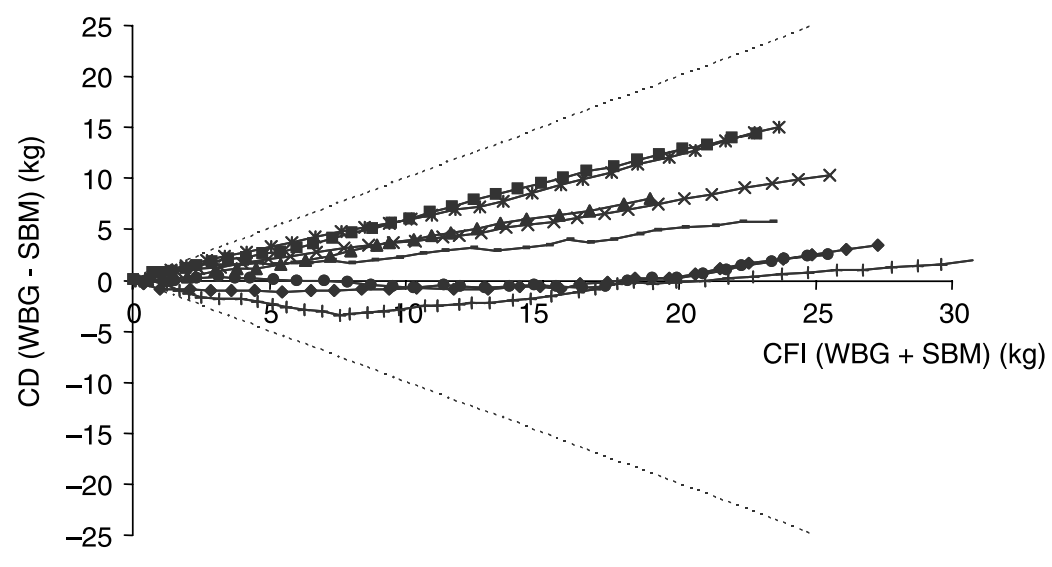

Figure 1 Selection paths of the W100S lambs (allowed no training period) given a choice between barley grain (WBG) and soya-bean meal (SBM). Each line is an individual lamb (trial 1). In all figures CD = cumulative difference between the intakes of WBG and SBM; CFI = cumulative feed intake. 


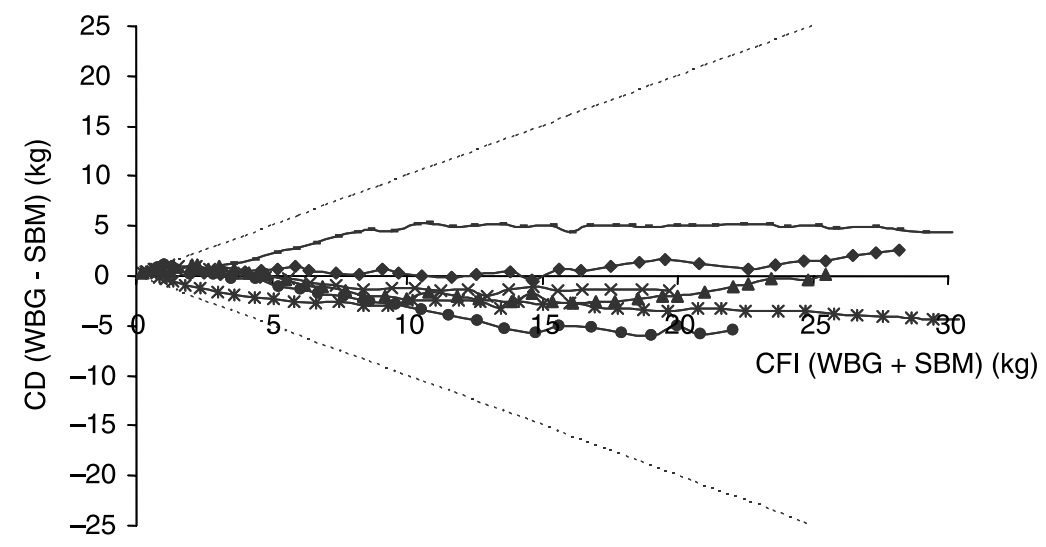

Figure 2 Selection paths of the W100S-T lambs (allowed an initial training period) given a choice between barley grain (WBG) and soya-bean meal (SBM), after an initial training period. Each line is an individual lamb (trial 1).

In the present study, however, it is plausible that the high protein intake was beneficial to the lambs and hence they selected a CP-rich diet. Lambs in the cafeteria groups consumed large amounts of starch-rich feeds, the mean values for starch intake being 490 (s.e. 24.8) g DM per day and 483 (s.e. 26.0) g DM per day for the W100S and W100S-T animals respectively (estimated data from Ministry of Agriculture, Fisheries and Food (1992)). This high intake can produce digestive disorders such as ruminal acidosis (Fraser and Ørskov, 1974; Gaebe et al., 1998; Bodas et al., 2006) and it has been suggested that high levels of rumen degradable protein in the diet might help maintain a higher ruminal pH (Van Soest, 1994). This feeding behaviour is in agreement with evidence suggesting that the objective of sheep, when selecting diets, is to achieve a high nutrient intake while maintaining a stable ruminal environment (Cooper et al., 1996; James et al., 2002).

It has been shown (James et al., 2002) that, in free choice systems, the intake of urea-supplemented diets seems to be reduced by the addition of a buffer such as sodium bicarbonate. This suggests that lambs might select diets with a high degradable protein content to reduce ruminal acidosis. However, as for protein intake excess, an excess of starch could induce negative post-ingestion consequences and lead to an aversion (Provenza, 1996; Arsenos and Kyriazakis, 1999). Arsenos and Kyriazakis (1999) reported that sheep can develop a conditioned aversion to casein, which is rapidly degraded to ammonia in the rumen. As a consequence, the diet selection pattern of the lambs might be partly associated with gradual changes in the degree of preference/aversion towards WBG and SBM.

Table 3 Carcass and non-carcass characteristics of lambs individually reared (trial 1) on conventional (control group) or cafeteria (W100S and W100S-T groups) feeding systems

\begin{tabular}{|c|c|c|c|c|c|c|}
\hline & \multirow[b]{2}{*}{ Control $(n=10)$} & \multicolumn{2}{|c|}{ Cafeteria systems } & \multirow[b]{2}{*}{ Residual s.d. } & \multicolumn{2}{|c|}{ Significance $^{\dagger}$} \\
\hline & & W100S $(n=8)$ & W100S-T $(n=6)$ & & P1 & $\mathrm{P} 2$ \\
\hline \multicolumn{7}{|l|}{ Carcass characteristics } \\
\hline Cold carcass weight $(\mathrm{kg})$ & 11.85 & 11.46 & 11.38 & 0.650 & & \\
\hline Dressing percentage (\%) & 47.6 & 45.8 & 45.6 & 2.46 & $\neq$ & \\
\hline Carcass conformation $(1-5)$ & 2.90 & 2.75 & 2.60 & 0.422 & & \\
\hline Carcass fatness $(1-4)$ & 2.80 & 2.88 & 2.60 & 0.426 & & \\
\hline Carcass kidney knob channel fat $(\mathrm{g})$ & 229 & 188 & 160 & 81.1 & & \\
\hline Carcass compact index $(\mathrm{g} / \mathrm{cm})$ & 229 & 226 & 217 & 13.8 & & \\
\hline Buttock/pelvic limb ratio $(\mathrm{cm} / \mathrm{cm})$ & 0.65 & 0.68 & 0.70 & 0.052 & & \\
\hline \multicolumn{7}{|l|}{ Non-carcass characteristics } \\
\hline Blood (g) & 1219 & 1213 & 1255 & 64.0 & & \\
\hline Wool (g) & 347 & 478 & 426 & 85.2 & * & \\
\hline Head and skin $(\mathrm{g})$ & 3703 & 3967 & 3811 & 253.7 & $\neq$ & \\
\hline Red offals $(\mathrm{g})$ & 1446 & 1483 & 1557 & 111.8 & & $\neq$ \\
\hline White offals (g) & 1824 & 1809 & 1927 & 175.5 & & \\
\hline Digestive fat $(\mathrm{g})$ & 488 & 417 & 385 & 85.4 & * & \\
\hline
\end{tabular}

\footnotetext{
${ }^{\dagger} \mathrm{P} 1=$ probability for control v. cafeteria contrast; $\mathrm{P} 2=$ probability for W100S $v$. W100S-T contrast.

${ }^{\ddagger}$ Approaching significance $(P<0.10)$.
} 
Rodríguez, Bodas, Fernández, López-Campos, Mantecón and Giráldez

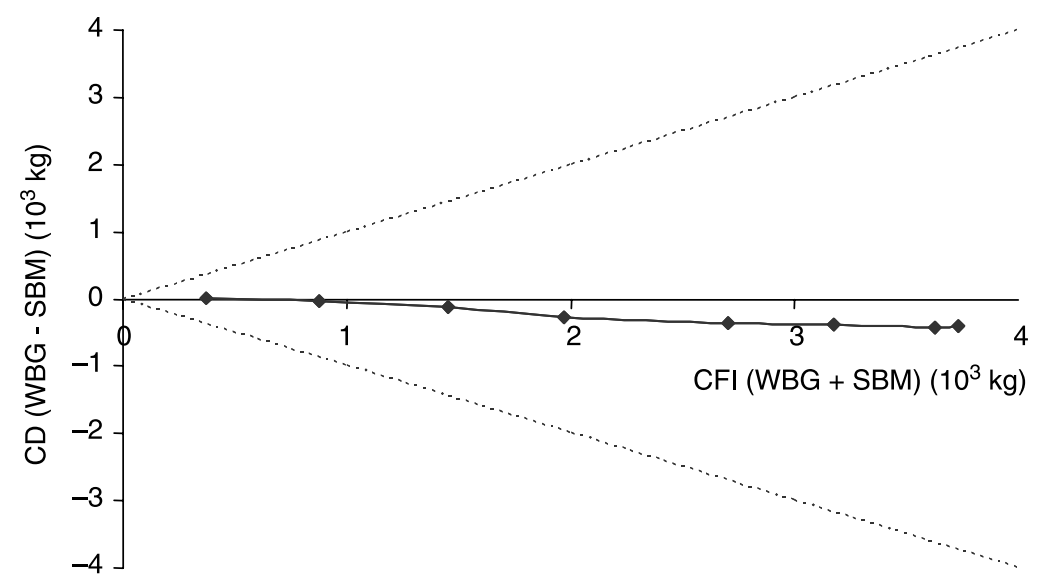

Figure 3 Selection path of W100S group given a choice between barley grain (WBG) and soya-bean meal (SBM) (trial 2).

Feed intake showed a tendency to be lower in the cafeteria groups. This effect on feed intake is in agreement with that reported by Cañeque et al. (2003), who indicated that the use of WBG in fattening lamb diets might negatively affect feed intake because of a reduction in the rate of digesta passage. However, if the reduction in feed intake is related to this, a greater feed intake would have been expected for the W100S-T than for the W100S lambs since the former selected a diet with a lower WBG content. In this regard, Askar (2004) observed no differences in rumen outflow in fattening lambs with respect to the form of barley grain administration (whole or ground). In addition, Rodríguez et al. (2003) reported the feed intake of Assaf lambs reared under a cafeteria system with barley grain and protein supplement ( $32 \% \mathrm{CP})$ to be higher than that of lambs fed barley straw and commercial concentrate. Similarly, other authors have failed to find differences in feed intake as a consequence of the use of whole or ground cereal grain (Askar et al., 2006).
Differences between the present feeding systems in feed conversion ratio might have been due to differences in the starch source (WBG v. ground barley) rather than to the feeding system per se. Other authors have reported an improvement in fibre digestibility (Askar, 2004), or cellulolytic activity (Ørskov et al., 1974; Castrillo et al., 1989) when WBG is used. Although the differences in feed efficiency among the treatments could be partly due to effects on the digestive utilisation of feed, differences in the chemical composition of the LW gain may also be involved. Certainly, the fat content and dressing percentage were slightly higher for the control group lambs. The weights of digestive fat deposits in these animals were greater and the weights of wool lower, which suggest that the protein supply was insufficient in relation to the energy available for tissue protein synthesis, and as a consequence more energy was deposited as fat than in the cafeteria system lambs. These differences were not manifested in other carcass characteristics, such as fatness or conformation,

Table 4 Feed intake, animal performance and carcass characteristics of lambs reared on conventional (control group) or cafeteria system (trial 2)

\begin{tabular}{|c|c|c|c|c|}
\hline & $\begin{array}{c}\text { Control } \\
(n=95)\end{array}$ & $\begin{array}{l}\text { Cafeteria } \\
(n=100)\end{array}$ & Residual s.d. & Significance \\
\hline Dry-matter intake (g/day) & 898 & 830 & - & - \\
\hline Organic-matter intake (g/day) & 837 & 770 & - & - \\
\hline Commercial concentrate (g/day) & 807 & - & - & - \\
\hline Barley straw (g/day) & 91 & - & - & - \\
\hline Whole barley grain (g/day) & - & 382 & - & - \\
\hline Soya-bean meal (g/day) & - & 424 & - & - \\
\hline Mineral and vitamin mixture (g/day) & - & 24 & - & - \\
\hline Average daily gain (g/day) & 282 & 309 & 60.7 & ** \\
\hline Days on trial & 47.9 & 45.7 & 6.37 & * \\
\hline Slaughter weight $(\mathrm{kg})$ & 26.0 & 26.6 & 2.01 & * \\
\hline Cold carcass weight $(\mathrm{kg})$ & 11.90 & 11.70 & 1.052 & \\
\hline Dressing percentage (\%) & 45.8 & 44.1 & 2.02 & $* * *$ \\
\hline Carcass conformation $(1-5)$ & 2.43 & 2.51 & 0.500 & \\
\hline Carcass fatness $(1-4)$ & 2.52 & 2.52 & 0.523 & \\
\hline Carcass compact index $(\mathrm{g} / \mathrm{cm})$ & 235 & 229 & 0.02 & \\
\hline
\end{tabular}


probably due to the low weight at which the lambs were slaughtered.

Trial 2 was performed on a commercial farm to evaluate the cafeteria feeding system under commercial conditions. Generally speaking, the results were in agreement with those obtained in Trial 1. Male and female lambs were reared together, as is usual in current feedlot practice; therefore the effect of sex on diet selection could not be studied. Nevertheless, the feeding system appeared to have no effect on LW gain in females (263 (s.e. 6.9) g/day and 272 (s.e. 6.4) g/day under the control and cafeteria feeding systems respectively), while the males of the cafeteria group appeared to grow faster than those of the control group (347 (s.e. 8.3) g/day and 301 (s.e. 8.4) g/day for cafeteria and control, respectively). These results are in agreement with those reported by González et al. (2000).

From a practical point of view, it is noteworthy that under the cafeteria feeding system no animal showed health problems and all were sent to slaughter. In the control group, however, two lambs were removed due to urolithiasis and another three lambs showed very low daily weight gains (less than $140 \mathrm{~g} /$ day).

Considering only the current cost of the different feeds, the cost of processing (grinding and pelleting) the experimental and commercial diets $(0.17$ v. $0.18 € / \mathrm{kg}$ DM intake), and the improvement in the feed to gain ratio and animal health, it seems that cafeteria feeding systems could contribute to the reduction of production costs (0.701 v. $0.659 \mathrm{E} / \mathrm{kg}$ CCW). Nevertheless, for a definitive conclusion to be reached, factors such as human resources, the repayment of loans and mortgages and cash return should all be taken into account.

In conclusion, cafeteria feeding system could be an economic alternative to conventional feeding systems for fattening lambs, although the results suggest that lambs reared under cafeteria feeding systems could consume protein in excess of that required to meet their tissue requirements. This could be negative from an environmental and economic point of view, depending on the price of the protein supplement and residue disposal costs. Further research is required to asses the factors influencing diet selection and how to improve the global efficiency of young lambs reared under cafeteria feeding systems.

\section{Acknowledgements}

This research was funded by Magnus S.A., with additional support from the collaboration between Caja España and the Estación Agrícola Experimental (CSIC, Spanish National Research Council).

\section{References}

Association of Official Analytical Chemists 2003. Official methods of analysis of the Association of Official Analytical Chemist, 17th edition. AOAC International, Gaithersburg MD.
Agricultural and Food Research Council 1995. Energy and protein requirements of ruminants. In An advisory manual prepared by the AFRC Technical Committee on Responses to Nutrients. CAB International, Wallingford.

Arsenos $G$ and Kyriazakis I 1999. The continuum between preferences and aversions for flavoured foods in sheep conditioned by administration of casein doses. Animal Science 68, 605-616.

Askar ART 2004. Alimentación de corderos con cebada en grano y suplemento proteico a libre elección: digestión ruminal, síntesis microbiana y rendimientos productivos. PhD thesis, University of Zaragoza, Spain.

Askar AR, Guada JA, González JM, de Vega A and Castrillo C 2006. Diet selection by growing lambs offered whole barley and a protein supplement, free choice: Effect on performance and digestion. Livestock Science 101, 81-93.

Bodas R, Giráldez FJ, López S, Rodríguez AB and Mantecón AR 2006. Inclusion of sugar beet pulp in cereal based diets for fattening lambs. Small Ruminant Research (available on line).

Cañeque V, Velasco S, Díaz MT, Huidobro FR, Pérez C and Lauzurica S 2003. Use of whole barley with a protein supplement to fatten lambs under different management systems and its effects on meat and carcass quality. Animal Research 52, 271-285.

Castrillo C, Guada JA and Gasa J 1989. Efecto del procesado de la cebada y la inclusión de paja en la dieta sobre su utilización por los corderos en cebo. Investigación Agraria: Producción y Sanidad Animal 4, 111-119.

Colomer-Rocher F, Delfa R and Sierra Alfranca I 1988. Metodo normalizado para el estudio de los caracteres cuantitativos y cualitativos de las canales ovinas producidas en el area Mediterránea, según los sistemas de producción (1). Cuadernos del INIA 17, 19-41.

Cooper SDB, Kyriazakis I and Oldham JD 1996. The effects of physical form of feed, carbohydrate source, and inclusion of sodium bicarbonate on the diet selection of sheep. Journal of Animal Science 74, 1240-1251.

European Commission 1994. Commission regulation (EEC) no. 1278/94 of 30 May 1994 laying down details rules for the Community scale for the classification of carcass ovine animals. Official Journal of the European Communities L140, 5-6.

European Commission 2003. Commission regulation (EEC) no. 65/2003 of 16 September 2003 laying down details rules for protection of the experimental animals. Official Journal of the European Communities L230, 32.

Fedele V, Claps S, Rubino R, Calandrelli M and Pilla AM 2002. Effect of freechoice and traditional feeding systems on goat feeding behaviour and intake. Livestock Production Science 74, 19-31.

Ferguson NS, Nelson L and Gous RM 1999. Diet selection in pigs: choices made by growing pigs when given foods differing in nutrient density. Animal Science 68, 691-699.

Fraser C and Ørskov ER 1974. Cereal processing and food quality by sheep. Animal Production 18, 75-83.

Gaebe RJ, Sansom DW, Rush IG, Riley ML, Hixon DL and Paisley SI 1998. Effects of extruded corn or grain sorghum in intake, digestibility, weight gain and carcasses of finishing steers. Journal of Animal Science 76, 2001-2007.

González JM, Janacua H, Guada JA, Castrillo C and Ferrer LM 2000. Cebo de corderos con cebada en grano y nucleo proteico. XXV Jornadas Científicas de la SEOC 1, 283-286.

Görgülü M, Kutlu HR, Demir E, ÖztLurkcan 0 and Forbes JM 1996. Nutritional consequences among ingredients of free-choice feeding Awassi lambs. Small Ruminant Research 20, 23-29.

James SM, Kyriazakis I, Emmans GC and Tolkamp BJ 2002. Diet selection of sheep: sodium bicarbonate, but not the offering of hay, modifies the effect of urea on diet selection. Animal Science 74, 357-367.

Keskin M, Sahin A, Biçer 0 and Gül S 2004. Comparison of the behaviour of Awassi lambs in cafeteria feeding system with single diet feeding system. Applied Behaviour Science 85, 57-64.

Kyriazakis I, Emmans GC and Whittemore CT 1990. Diet selection in pigs: choice made by growing pigs given foods of different protein concentrations. Animal Production 51, 189-199.

Kyriazakis I and Oldham JD 1993. Diet selection in sheep: the ability of growing lambs to select a diet that meets their crude protein (nitrogen $\times 6.25$ ) requirements. British Journal of Nutrition 69, 617-629.

Landa R, Mantecón AR, Frutos $P$, Rodríguez $A B$ and Giráldez FJ 2001. Efecto del tipo de cereal (cebada vs maíz) sobre la ingestión, la ganancia de peso y las características de la canal de corderos alimentados con pienso y paja 0 solo con pienso. ITEA 97A, 204-216. 


\section{Rodríguez, Bodas, Fernández, López-Campos, Mantecón and Giráldez}

Manso T, Mantecón AR, Giraldez FJ, Lavín P and Castro T 1998. Animal performance and chemical body composition of lambs fed diets with different protein supplements. Small Ruminant Research 29, 185-191.

Ministry of Agriculture, Fisheries and Food 1992. Feed composition. In UK tables of feed composition and nutritive value for ruminant. Chalcombe Publications, Canterbury.

Ørskov ER, Fraser C and Gordon JG 1974. Effect of processing of cereals on rumen fermentation, digestibility, rumination timen and firmness of subcutaneous fat in lambs. British Journal of Nutrition 32, 59-69.

Provenza FD 1996. Acquired aversions as the basis for varied diets of ruminants foraging on rangeland. Journal of Animal Science 74, 2010-2020.

Robertson E, Gordon IJ and Pérez-Barbería FJ 2006. Preferences of sheep and goats for straw pellets treated with different food-flavouring agents. Small Ruminant Research 63, 50-57.

Rodríguez $A B$, Landa $R$, Giráldez FJ, Frutos $P$ and Mantecón AR 2003. Estrategias de alimentación basadas en la libre elección de alimentos en el cebo de corderos de raza Assaf. ITEA 24, 591-593.

Russo C, Preziuso $G$ and Verità $P$ 2003. EU carcass classification system: carcass and meat quality in light lambs. Meat Science 64, 411-416.
Sahin A, Keskin M, Biçer 0 and Gül S 2003. Diet selection by Awassi lambs fed individually in a cafeteria feeding system. Liverstock Production Science 82, 163-170.

Sañudo C, Santolaria MP, María G, Osorio M and Sierra I 1996. Influence of carcass weight on instrumental and sensory lamb meat quality in intensive production systems. Meat Science 42, 195-202.

Statistical Analysis Systems Institute 1999. SAS/STAT ${ }^{\circledR}$. user's guide (version 8). SAS Inc., Cary, NC.

Tait RM and Bryant G 1973. Influence of energy source and physical form of all-concentrate rations on early weaned lambs. Canadian Journal of Animal Science 53, 89-94.

Tolkamp BJ and Kyriazakis I 1997. Measuring diet selection in dairy cows: effects of training on choice of dietary protein level. Animal Science 64, 197-207.

Van Soest PJ 1994. Nutritional ecology of the ruminant, 2nd edition. Cornell University Press, Ithaca, NY.

Van Soest PJ, Robertson JB and Lewis BA 1991. Methods for dietary fiber neutral detergent fiber and nonstarch polysaccharides in relation to animal nutrition. Journal of Dairy Science 74, 3583-3597. 